\title{
СОВРЕМЕННОЕ ОБРАЗОВАНИЕ В СВЕТЕ ИДЕЙ ГЕГЕЛЕВСКОЙ ФИЛОСОФИИ
}

\section{И.А.Коваль, А.В. Пасечник}

Философское осмысление процесса развития образования и его концептуальное оформление позволяют критично фиксировать противоречия теории и практики образования, информировать общественность о последствиях социально-педагогического экспериментирования и избегать культурных катастроф. Ведь образование уже в силу своей обращенности в будущее может нести в себе как конструктивный, так и деструктивный потенциал. Без какого-либо преувеличения можно констатировать, что постиндустриальное общество, составляющее основной вектор эволюции человеческой цивилизации, характеризуется ускоряющейся динамикой влияния социально-педагогических факторов на фундаментальные характеристики социума (см.: [6]).

Обсуждение проблем образования с позиций педагогики в своих предельных границах приводит к пониманию самого образования или как сферы потребительских услуг (с соответствующими реверансами в сторону уникальности, специфичности именно этой сферы), или как производственной отрасли, которая поставляет социуму содержательный материал, позволяющий ему не только сохраняться, но и эволюционировать (см.: [7]).

В более широком социокультурном аспекте образование рассматривается значительно реже. Но именно этот аспект представляет особый интерес для исследователей. В работах Г.С.Батищева, М.М. Бахтина, В.С. Библера, Ю.В. Громова, В.В. Давыдова, Э.В. Ильенкова, В.В. Корженко, М.К. Мамардашвили, А.Швейцера, Г.П. Щедровицкого прослеживаются принципиально иные подходы к образованию, которые не вмещаются в рамки традиционной педагогики. Педагогика, в их

Актуальні проблеми духовності:

зб. наук. праць / Ред.: Я.В. Шрамко

Вип. 10. - Кривий Ріг, 2009, 198-205 
понимании, - всего лишь техника и технология процесса образования. Подобный лейтмотив в значительной степени характерен уже для концепции образования Нового времени, и в частности, для концепции образования Г. Гегеля. Именно в ней образование начинает рассматриваться как ценностный критерий социального бытия человека, с одной стороны, и как смыслообразующий императив духовной культуры социума - с другой. Этим самым подтверждается древняя истина: нельзя испортить человека избытком образования и нравственности.

Усилившееся в последние годы ощущение стагнации образования, выражающееся в неудовлетворенности его результатами, а также в традиционной консервативности образовательной системы, не имеющей финансовых возможностей и не всегда желающей учитывать динамизм общественной жизни, приводит к выхолащиванию ценностнонравственного и смыслообразующего стержня системы образования. В итоге образуется разрыв между уровнем подготовки специалистов и потребностями общества (см.: [4]).

Неудовлетворенность образованием стала всеобей: и власть, и общественность, и педагоги, и студенты, и школьники предъявляют образованию целый набор претензий, не всегда оказываясь способными сформулировать свое видение путей и методов его реформирования. Другими словами, во всем мире идет процесс пересмотра основных установок применительно к пониманию человека, знания, возможностей и условий его трансляции, унаследованных от эпохи Просвещения. Ведь именно эти установки были положены в основу системы образования и до последнего времени считались само собой разумеющимися. Образование же исповедовало идею прямой зависимости освобождения человека из-под гнета чуждых ему природных и социальных сил от овладения знаниями природы и социального бытия. Считалось, что используя эти знания, человек в состоянии управлять разнообразными процессами, контролировать их и использовать в собственных интересах. Отсюда становится понятным, что основная функция образования сводилась к обретению соответствующих знаний, навыков, умений.

Новое время приступает к выработке такой парадигмы образования, которая была бы способна переработать весь опыт образовательной деятельности, не упустить рациональных моментов, а наоборот, придать им новый импульс развития. Этому соответствует и этимология термина «образование», ориентирующего, прежде всего, на процессуальность определенных действий, которые, в конечном счете, имеют цель построения, оформления и появления из элементов сущего какой- 
то новой целостности. Применительно к человеку образовательный процесс выглядит в форме «образования» ученика под воздействием «образовательных» усилий учителя.

Однако, этим не исчерпывается содержательный смысл термина «образование». В этом термине имманентно присутствует еще один его аспект, а именно, формирование «образа» как целостности, способности творить «образы-целостности», посредством которых раскрывается содержание постигаемой действительности, включающей и формирование своего собственного образа. Таким образом, образование не следует сводить до реакции индивида на внешние условия, оно индуцирует его (индивида) на самостоятельные усилия по формированию своего собственного образа, на «самообразование».

Подобному философскому пониманию термина «образование»не противоречит и теологизированная версия данного социокультурного феномена. На это обращает внимание Н.В. Карлов, когда констатирует: «Наши далекие предки вкладывали в содержание слова „образование“ сотворение образа человека, подобного Богу или в крайнем случае стремящегося к нему. Как смело это не звучит, но Книга Бытия утверждает сотворение человека Господом по образу своему и подобию. Обожествление творческого начала - вот о чем речь идет в слове „образование“» [5, с. 7].

Несомненный приоритет в выделении и философском анализе феномена образования принадлежит Г. Гегелю, который понимает этот феномен в предельно широком смысле: как процесс приобщения конкретно-исторического индивида к наличной системе культуры. Исходным пунктом Гегеля становится одновременно и противопоставление индивидом себя сообществу, и объединение его с ним как с воплощением родовой сущности человека. Наличное бытие (и природное, и социокультурное) рассматривается мыслителем как «неорганическая природа» индивида, как та реальность, которая существует вне индивида и независимо от него. В силу этого четко фиксируется извечное противостояние двух элементов социального бытия индивида, когда имеется в наличии, «с одной стороны, сама индивидуальность, а с другой-ее общая неорганическая природа, то есть в наличии есть обстоятельства, ситуации, обычаи, религия и т.д.» [1, с. 163].

Контекст «Феноменологии духа» свидетельствует, что «неорганическая природа» у Гегеля - синоним понятия «культура», когда последняя берется не в процессуальной форме, а в объективно существующих, сложившихся, результирующих формах. Поэтому Гегель относит к «неорганической природе» практически все воплощения человече- 
ской деятельности: и обработанные и преобразованные трудом предметы природы, и формообразования умственной деятельности, формообразования сознания.

Таким образом, сущностные характеристики человека, согласно Гегелю, локализуются в мире культуры. Этот мир противостоит индивиду до тех пор, пока он не переведет его в содержание своей духовной культуры. Содержащийся в культуре широкий спектр деятельностных способностей в процессе образования из потенциальной, виртуальной формы переходит в форму объективных характеристик индивида, который начинает соотносить свою индивидуальность с человечеством и тем самым превращается в носителя родовых сущностных сил человека. В силу этого представляется справедливым тезис: образование по своей сути никогда не может быть завершенным.

Последний момент составляет своеобразное ядро гегелевского понимания феномена образования. Он позволяет относиться к индивиду не просто как к продукту культуры, а как к продукту деятельности, которой и была эта культура создана. Другими словами, индивид выступает и как объект, и как субъект деятельности: в первом случае, как индивид, которому дается его «неорганическая природа», его социальная, родовая сущность; во-втором, - как соучастник совместной деятельности, которая творит мир культуры, т.е. как общественное существо. Гегель разделяет, в основном, просветительскую концепцию образования, делая акцент на том, что субъектом образования может быть лишь индивид, ценный сам по себе, который волевым усилием и под перманентным руководством разума входит в коллектив, общество, государство.

Однако, не стоит забывать, что эффективность образовательного процесса во многом зависит также и от степени гармонизации разумного и чувственного. Индивид, во всей полноте его проявления, может состояться только тогда, когда он устранит раздвоенность между разумом и чувственностью, а при принятии разумных решений будет руководствоваться чувством личной ответственности.

Опыт кантовской «Критики чистого разума» показывает, что рафинированный разум плохо приспособлен для решения обыденных жизненных коллизий, а потому своеобразным дополнением ему должна стать определенным образом сформированная чувственность.

В данной ситуации было бы неразумным отстаивать тот status quo, который сложился в системе образования. Ведь и формы, и методы, и содержание образования, сохраняя традиционные для предыдущего периода цели и средства их воплощения, вступают в противоречие с 
тенденциями, которые укореняются в общественной жизни и определяют новые векторы социальной эволюции.

Правда, в этом случае определяющую роль начинает играть позиция индивида относительно тех феноменов культуры, которые подлежат «присвоению». Общественный дух, считает Гегель, представляя субстанцию индивида, его «неорганическую природу», проявляется во внешнеположенных формах культуры, в формах обработанного человеком природного материала. Индивид «присваивает» не готовые результаты развития культуры, а результаты вместе с процессом, который их породил и порождает, т. е. вместе с историческими обстоятельствами. В этом, собственно, и состоит, по Гегелю, фундаментальность системы образования.

Концепция европейского образования, ориентированная на принципы всестороннего развития индивида и гуманистические ценности, берет начало, пожалуй, с Академии Платона и Ликея Аристотеля. Именно здесь закладывались основы понимания образования как процесса перманентного освоения духовных основ человеческого бытия. Мыслители всех народов всегда склонялись к данной концепции. Г. Сковорода свой трактат «Начальная дверь к христианскому добронравию» начинает словами: «Благодарение блаженному Богу о том, что нужное сделал нетрудным, а трудное - ненужным» [8, с. 111].

Бог, согласно Г. Сковороде, открывает человеку путь к обретению абсолютного знания и счастья, но в то же время счастливые и интеллектуально воспитанные люди - исключительность в этом мире. Причина одна: весь мир «спит» вместо того, чтобы «обрабатывать сердца молодых». Активизация воздействия на человеческие души рассматривается мыслителем как Дело, имманентное духовной сути и назначению человека. Все иные виды деятельности - всего лишь Поделие, дополнение к Делу.

Мыслитель исходит из допущения, что освоение духовных основ своего бытия не должно быть сложным делом в том случае, когда индивид получает систематическое образование и постоянно его совершенствует. Здесь срабатывает одна парадоксальная особенность процесса познания: с расширением и углублением человеческих знаний, возможности выбора поведения человека суживаются. В конце концов у человека вообще не остается выбора, и он делает только то, что должен делать. В данном случае представляет особый интерес принципиальное совпадение идей великого украинского философа с идеями великого немецкого философа относительно социального статуса образования и его роли в духовной эволюции человечества. 
Следует иметь в виду следующее, весьма немаловажное, обстоятельство. Начиная с Античности и вплоть до Нового времени образование было сугубо гуманитарным. Теология, философия, логика, риторика, этика и эстетика - обязательные дисциплины университетского образования Средневековья. Только в Новое время в связи с освоением природных богатств, система образования начинает перестраиваться под социальный заказ. Отсюда вполне понятны утилитарность и «приземление» целей образования. Субсидируется подготовка только таких специалистов, которые были бы в состоянии обеспечивать наращивание экономического потенциала. Подобная тенденция к утилитаризации образования реализуется прежде всего в появлении институтов, которые берут на себя своеобразную функцию конвейеров по производству узких специалистов.

В отличие от институтов, университеты традиционно ориентированы на культивирование высокой духовности, что в наши дни становится стимулом преобразования институтов, т.е. основных проводников узкопрофессионального образования, в университеты. «Концепция гуманитарного образования в Украине (Высшая школа)», Государственная национальная программа «Образование», Государственная программа «Молодежь Украины», Национальная доктрина развития образования в Украине ставят рядом, как неразрывные, такие базовые понятия как «образование», «воспитание» с понятием «духовность». Казалось бы, этими документами однозначно определяется основной вектор высшего образования: специалист обязан быть носителем высокой духовности, а система образования должна взять на себя заботы о формировании базы его интеллектуального потенциала.

Практика внедрения новых ориентиров образования, однако, существенно расходится с теоретическими установками. Весьма часто реформа высшей школы исчерпывается сменой вывески на стене учебного заведения. Вследствие этого вновь образованные университеты, будучи официально ориентированными на культивирование высокой духовности, продолжают годами апробированную практику подготовки узких специалистов, не обращая внимания на формирование их духовности. Духовность воспроизводится только от человека к человеку, ее нельзя формировать заочно. В человеческом сознании существует область значений, т.е. обычной информации, и область смысла, т.е. информации, содержащей в себе индивидуальные переживания. В наши дни происходит бурное развитие, «разбухание» области значений, области овладения данными, и существенно отстает то, что определяет характер использования этих данных, область смысла. Следствием 
этого становится появление экзистенциального вакуума, ведущего к утрате смысла жизни, к абсурду самого факта существования. Возвратить смысл и стабильность индивидуального бытия становится возможным только в пространстве духовности.

Компьютеризация образования, несомненно, приводит к наращиванию информационного потока, который и без того предельно интенсивный. Но оперативность доступа к информации и скорость ее обработки порождает упрощенное представление об образовании: усвоение знаний подменяется умением оперировать информацией. На этой основе, как отмечает Йонези Масуда, формируется новый тип человека: на место homo sapiens приходит homo intelectus, т. е. человек, соориентивованный исключительно на предельно мощный интеллект. Социуму же нужен человек духовный, homo humanus [9, с.62].

$\mathrm{C}$ позиции новой парадигмы высшего образования принципиальным недостатком современного научного знания является его фрагментарность, что тормозит развитие науки и не позволяет ей выйти на целостную картину мира. Новая парадигма высшего образования исходит из того, что возникает множество глобальных проблем, угрожающих самому существованию человечества, требующих для своего осознания и разрешения интегральных знаний и объединенных усилий. Именно в таком направлении, по мнению авторов, идеи гегелевской философии могут способствовать становлению современной концепции образования.

При этом гегелевская программа образования в меру детализирована, оставаясь на методологическом уровне, она не нисходит до уровня конкретных методических рекомендаций. Гегель утверждает, что благодаря образованию дается толчок развитию сознания индивда, и сущность реального мира, спрятанная от непосредственного наблюдения, «выступает в бесконечном богатстве форм, явлений и образований» [2, с. 15]. Теперь остается постичь причины этого разнообразия, свести его к единству, к конкретности. На этом пути изменяется картина внешнего мира, изменяется сам индивид, развивается его сознание, его воля, побуждая к еще более активному постижению и мира, и себя.

Изменение индивидом самого себя в процессе образования, таким образом, вызывается не только и не столько внешними побудительными факторами, «ему присуще стремление порождать самого себя в том, что ему непосредственно дано, что существует для него как нечто внешнее и, таким образом, познавать себя также и в этом внешне данном» [3, с. 33]. Под этими словами мыслителя, несомненно, подпишутся фундаторы и адепты новой парадигмы образования. 


\section{1 Литература}

[1] Гегель Г.В.Ф. Феноменология духа // Сочинения. - М.: Соцэкгиз, 1959. - T. 4.

[2] Гегель Г.В.Ф. Философия права // Сочинения. - М.-Л.: Соцэкгиз, 1934. - T. 7 .

[3] Гегель Г.В.Ф. Лекции по эстетике. Кн. 1 // Сочинения.- М.-Л.: Соцэкгиз, 1938. - Т. 12.

[4] Золотухін Г. Освіта не товар, студенти - не покупці // Соціальна психологія. -2005 . - № $1(9)$. - С. 14-36.

[5] Карлов Н.В. Преобразование образования // Вопросы философии. -1998 . - № 1 . - С. 3-19.

[6] Козаков В. Вища освіта в Україні та у світі: проблема цілей і їх реалізації // Сучасні системи вищої освіти: порівнення для України. - K.: K.M. Academia, 1997. - С. 34-56.

[7] Петрелла Р. Пять «ловушек» на пути развития образования // Социология образования. -2003 . - № 5.

[8] Сковорода Г.С. Соч. в 2-х т. - Т. 1.-М.: Мысль, 1973.

[9] Masuda J. The information Society as Past-Industrial Society.Washington, 1981. 